\title{
Toxicity of two effluents from agricultural activity: Comparing the genotoxicity of sugar cane and orange vinasse
}

\author{
Camila Fernandes H. Garcia ${ }^{a}$, Raphael B. de Souza ${ }^{a}$, Cleiton Pereira de Souza ${ }^{a}$, \\ Cintya Ap. Christofoletti ${ }^{\mathrm{b}}$, Carmem S. Fontanetti $\mathrm{i}^{\mathrm{a}, *}$

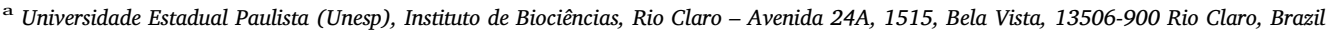

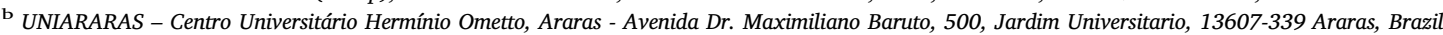

\section{A R T I C L E I N F O}

\section{Keywords:}

Citrus stillage

Sugar cane stillage

Fertirrigation

Micronucleus

Mutagenicity

\begin{abstract}
A B S T R A C T
Vinasse, produced by several countries as a by-product of agricultural activity, has different alternatives for its reuse, mainly fertirrigation. Several monocultures, such as sugar cane and orange crops, produce this effluent. Sugar cane vinasse is already widely used in fertirrigation and orange vinasse has potential for this intention. However, its use as a fertilizer has caused great concern. Thus, ecotoxicological evaluation is extremely important in order to assess the possible effects on the environment. Therefore, the aim of this study was to evaluate the potential toxicity of vinasse of two different crops: sugar cane and orange. For this purpose, bioassays with Allium cepa as a test organism were performed with two vinasse dilutions ( $2.5 \%$ and $5 \%$ ) to detect chromosomal aberrations and micronucleus induction. The results showed that both types of vinasse are able to induce chromosomal aberrations in meristematic cells, mainly nuclear and anaphasic bridges, suggesting genotoxic potential. The induction of micronuclei in cells of the $\mathrm{F}_{1}$ region suggests that the two residues have mutagenic potential. Thus, caution is advised when applying these effluents in the environment.
\end{abstract}

\section{Introduction}

Over the last few decades, the world has been faced with an increase in the consumption of raw materials and waste generation in agriculture and agro-industrial activities due to the significant advances of agribusiness. Thus, special attention has been focused on minimizing these effluents and in their reuse (Rosa et al., 2011).

Vinasse, produced in many countries as a by-product of agricultural activities, is obtained after fermentation processes of different raw materials such as sugar cane, orange, corn and beet (Christofoletti et al., 2013a). Depending on the raw material that produces it, the physical and chemical properties can be different (España-Gamboa et al., 2011).

Since its introduction in Brazil, sugar cane (Saccharum sp.) has gained prominence in agricultural activities of socio-economic expression. Consequently, the waste generated by the sugar and alcohol industry, mainly vinasse, has also increased (Pedrosa et al., 2005). In 2014, Brazil produced 28.6 billion liters of ethanol (EPE, 2015), and for each liter produced, about $13 \mathrm{~L}$ of vinasse is generated (Neto, 2008).

As well as the sugar and alcohol industry, the orange juice processing industry also produces a high volume of solid and liquid waste daily. The solid waste is formed by the peel, seed and pulp and can be reused as animal feed; liquid waste is discharged into water sources after treatment (Rezzadori and Benedetti, 2009; Tavares et al., 1998). Through fermentation of the sugars found in the pulp liquor it is possible to produce second-generation ethanol (Citrosuco, 2016), thus obtaining orange vinasse as a by-product.

Regardless of the raw material utilized in its production, the main component of vinasse is organic matter in the form of organic acids and cations, such as potassium, calcium and magnesium. In general, this effluent has a dark color and consists primarily of water (93\%) and organic and mineral solids (7\%). Despite having high levels of organic matter, it has low levels of nitrogen and phosphorus (Laime et al., 2011).

There are several alternatives for its reuse and fertirrigation is the most common for sugar cane vinasse due to its high fertilizer value (Christofoletti et al., 2013a). In Brazil, the liquid waste originated by the orange industry is subjected to a biological treatment system in order to achieve the standards required by the environmental legislation; after this process, it can be released into water sources (Rezzadori and Benedetti, 2009). As orange vinasse presents similar characteristics to sugar cane vinasse, it has potential use as a fertilizer in agriculture. A study using the liquid effluents of the citrus industry on the corn crop has already been done by Aloisi et al. (2001).

The agricultural use of vinasse and its benefits are unquestionable

\footnotetext{
* Corresponding author.

E-mail address: fontanet@rc.unesp.br (C.S. Fontanetti).
} 
from the agricultural, economic and social point of view (Giachini and Ferraz, 2009). However, its application has been questioned by its adverse effects on soil and groundwater and, consequently, to the biota present in these environments (Christofoletti et al., 2013a; Silva et al., 2007).

Studies have been carried out mainly with sugar cane vinasse and several authors have concluded that this effluent can be toxic. Marinho et al. (2014), Pedro-Escher et al. (2014), Christofoletti et al. (2016) and Correia et al. (2017) observed its toxicity to different bioindicator organisms, such as fish, millipedes and Tradescantia pallida. There are no studies about the toxicity of orange vinasse, but Saverini et al. (2012) analyzed the genotoxicity of citrus wastewater derived from the production of citrus juice and the extraction of essential oils in the Salmonella reversion assay (Ames test) and in V79 cells by Comet assay. The authors concluded that the wastewater is highly genotoxic in bacterial and mammalian cells.

Tests that assess the genotoxic and/or mutagenic potential of this effluent are of the utmost importance. The use of higher plants, such as Allium cepa, can be employed for the evaluation of these parameters, since they are recognized as excellent models to detect environmental genotoxic agents (Leme and Marin-Morales, 2009). The bioassay using A. серa is validated and standardized by the International Program on Plant Bioassays (IPPB) conducted by the United Nations Environment Program (UNEP) (Ma, 1999). Recently, this organism has been employed to detect the genotoxicity of pesticides (Kuchy et al., 2016; Rodríguez et al., 2015; Souza et al., 2017), sewage sludge (Martins et al., 2016), river water samples (Batista et al., 2016) and drugs (Lutterbeck et al., 2015; Pichler et al., 2014).

Thus, this study aimed to compare the genotoxic potential of two different types of vinasse, derived from sugar cane and orange crops, analyzing the induction of micronuclei and chromosomal aberrations in meristematic cells and the $\mathrm{F}_{1}$ region in $A$. cepa.

\section{Materials and methods}

\subsection{Biological material}

The bioassays were performed with A. cepa (Amaryllidaceae) seeds of the variety Baia Perform. All seeds used in the experiment had the same brand, lot number and expiration date in order to avoid different responses to the various stages of the test.

\subsection{Vinasse samples}

The sugar cane and orange vinasse samples used in these experiments were collected in the State of São Paulo, Brazil. In the laboratory, the samples were stored in a refrigerator at $4{ }^{\circ} \mathrm{C}$ until the beginning of the experiments. In order to perform the seed exposure, both types of vinasse were diluted in ultrapure water in two different dilutions: $5 \%$ and $2.5 \%$. The concentrations were chosen after preliminary seed germination tests in both types of vinasse. According to these data, the seeds exposed to orange vinasse did not germinate at concentration above $5 \%$.

\subsection{Physicochemical analysis of the vinasse samples}

Physical and chemical analysis of raw vinasse (undiluted) was performed by the São Lucas Environmental Analysis Laboratory (Rio Claro, São Paulo, Brazil) to detect the following parameters: $\mathrm{pH}$, nonfilterable residue, hardness, conductivity, nitric nitrogen, nitrous nitrogen, ammonia, Kjeldahl nitrogen, sodium, calcium, potassium, magnesium, sulfate, phosphate, BOD (biochemical oxygen demand), COD (chemical oxygen demand), $\mathrm{K}_{2} \mathrm{O}$ content and metals ( $\mathrm{Sb}, \mathrm{As}, \mathrm{Ba}, \mathrm{B}, \mathrm{Cd}$, $\mathrm{Pb}, \mathrm{Co}, \mathrm{Cu}, \mathrm{Cr}, \mathrm{Hg}, \mathrm{Mo}, \mathrm{Ni}, \mathrm{Ag}, \mathrm{Se}, \mathrm{Zn}, \mathrm{Fe}, \mathrm{Mn}$ and $\mathrm{Al}$ ).

\subsection{A. cepa bioassays}

One hundred A. cepa seeds were placed in Petri dishes containing filter paper. Seeds were directly exposed to $4 \mathrm{~mL}$ of different dilutions $(2.5 \%$ and $5 \%)$ of sugar cane and orange vinasse. Ultrapure water was used as a negative control, while methyl methanesulfonate (clastogenic action) at the concentration of $4 \times 10^{-4} \mathrm{M}$ (Rank and Nielsen, 1997) was used as the positive control. The experiment was conducted in laboratory incubator with controlled photoperiod (12:12) and temperature $(22 \pm 1 \stackrel{\circ}{\circ})$. Bioassays were performed in triplicate.

\subsection{Preparation of A. cepa slides}

After 5 days of exposure, the radicles, approximately $2 \mathrm{~cm}$ in length, were collected and fixed in Carnoy 3:1 (ethanol:acetic acid, v/v) for 6-12 h. After this process, the radicles were transferred to a new Carnoy fixative and stored at $4{ }^{\circ} \mathrm{C}$ until use (Souza et al., 2017; Rodríguez et al., 2015). For preparation of the slides, the radicles were subjected to acid hydrolysis for $9 \mathrm{~min}$ in $1 \mathrm{~N} \mathrm{HCl}$ at $60^{\circ} \mathrm{C}$ and then submitted to Schiff's reagent for $2 \mathrm{~h}$. Both the meristematic and $\mathrm{F}_{1}$ regions were sectioned and placed on the slide. In order to enhance the coloration and to facilitate spreading of the cells, a drop of $2 \%$ acetic carmine was added to the material. All slides were obtained by subjecting the material to soft crushing between slide and coverslip. Coverslips were extracted in liquid nitrogen and permanent slides were mounted with Entellan.

\subsection{Analysis of the results}

The material was analyzed on a light microscope under $1000 \times$ magnification. Three hundred cells from the meristematic region and 300 cells from the $F_{1}$ region were analyzed per slide. Fifteen slides were analyzed per treatment, totaling approximately 5000 cells for each region. After analyzing all triplicates, the total of cells observed was approximately 15,000 per dilution. The genotoxicity was assessed by the frequency of micronuclei (FMN) and the quantification of cells carrying chromosomal aberrations (CA) at different stages of cell division (prophase, metaphase, anaphase and telophase), such as chromosome stickiness, chromosome bridges, C-metaphase, chromosomal delays and nuclear buds, through the formulas $\mathrm{FMN}=$ (number of cells with $\mathrm{MN} /$ number of cells observed) $\times 100$ and $\mathrm{CA}=$ (number of cells with $\mathrm{CA} /$ number of cells observed) $\times 100$. The mutagenic potential was verified by the FMN in the $F_{1}$ region. The values obtained were compared with those obtained in the negative control through a Kruskal-Wallis statistical test $(\mathrm{p}<0.05)$.

\section{Results}

\subsection{Physicochemical characterization of the vinasse}

The values obtained by the physicochemical analysis of sugar cane and orange vinasse are shown in Table 1.

Sugar cane vinasse showed higher amounts of potassium, magnesium, $\mathrm{K}_{2} \mathrm{O}$ and higher electrical conductivity, while orange vinasse showed higher amounts of non-filterable residue, ammoniacal and Kjeldahl nitrogen, sodium, calcium, sulfate and phosphate, as well as higher values of COD, BOD and hardness.

The values obtained by analysis of the sugar cane and orange vinasse concerning the presence of metals are shown in Table 2. In sugar cane vinasse, aluminum, barium, cobalt, copper, iron, manganese, nickel and zinc were detected; in orange vinasse, only barium and zinc were measured.

\subsection{Genotoxic and mutagenic evaluation}

\subsubsection{Sugar cane vinasse}

Both dilutions tested, $2.5 \%$ and $5 \%$, showed a genotoxic effect, since 
Table 1

Physicochemical analysis of the two vinasse samples.

\begin{tabular}{|c|c|c|c|}
\hline Parameters & Method & Sugarcane vinasse & Orange vinasse \\
\hline pH & - & 4,6 & 4,1 \\
\hline Non-filtrable residue (mg/L) & $2540 \mathrm{D}$ & 1190 & 16,940 \\
\hline Hardness $\left(\mathrm{mg} \mathrm{CaCO}_{3} / \mathrm{L}\right)$ & $2340 \mathrm{~B}$ & 3390,4 & 6413,3 \\
\hline Eletric Conductivity ( $\mu \mathrm{s} / \mathrm{cm})$ & 2510 B & 8294 & 7904 \\
\hline Nitric Nitrogen (mg/L) & USEPA 300.1 & $<\mathrm{QL}^{*}$ & $<\mathrm{QL}^{* * *}$ \\
\hline Nitrous Nitrogen $(\mathrm{mg} / \mathrm{L})$ & USEPA 300.1 & $<\mathrm{QL}^{*}$ & $<\mathrm{QL}^{* * *}$ \\
\hline Amoniacal Nitrogen (mg NH3-N/L) & $4500-\mathrm{NH}_{3} \mathrm{D}$ & 10,920 & 44,115 \\
\hline Kjeldahl Nitrogen (mg NH$\left.H_{3}-\mathrm{N} / \mathrm{L}\right)$ & 4500 - Norg B & 234,1 & 651,8 \\
\hline Sodium (mg/L) & 3030E USEPA $6010 \mathrm{C}$ & 13,570 & $97,950 * *$ \\
\hline Calcium (mg/L) & 3030E USEPA 6010C & $828^{* *}$ & $2275,50 * *$ \\
\hline Potassium (mg/L) & 3030E USEPA $6010 \mathrm{C}$ & $3276^{\circ}$ & $2237,25^{* *}$ \\
\hline Magnsium (mg/L) & 3030E USEPA 6010C & $321,250 * *$ & $177,875^{* *}$ \\
\hline Sulfate $(\mathrm{mg} / \mathrm{L})$ & USEPA 300.1 & $340,276^{*}$ & $432,150^{\circ}$ \\
\hline Phosphate (mg/L) & USEPA 300.1 & $5518^{*}$ & $173,020^{\circ}$ \\
\hline BOD (mg/L) & 5210 в & 13394,3 & 47636,3 \\
\hline $\mathrm{COD}\left(\mathrm{mg} \mathrm{O}_{2} / \mathrm{L}\right)$ & $5220 \mathrm{D}$ & $31723,2^{* * *}$ & 107014,4 \\
\hline $\mathrm{K}_{2} \mathrm{O}$ content $\left(\mathrm{kg} \mathrm{K}_{2} \mathrm{O} / \mathrm{m}^{3}\right)$ & 3030E USEPA 6010C & $3,931^{\circ}$ & $2685^{* *}$ \\
\hline
\end{tabular}

QL: Quantification Limit; *: dilution 20; **: dilution 25; ***: dilution 50; ㅇ: dilution 100;

induction of CA in meristematic cells was observed. The alterations found were nuclear buds (Fig. 1A), anaphasic bridges (Fig. 1B), MN (Fig. 1C), chromosomal loss (Fig. 1D) and chromosomal break (Fig. 1E). Table 3 contains all the alterations observed. Both the frequency of CA and MN were similar in the two dilutions (Table 4). Analysis of the cells of the $F_{1}$ region revealed the presence of $\mathrm{MN}$ in the two dilutions, demonstrating the mutagenic potential of the residue. However, the FMN in the 5\% dilution was higher (2.2-fold higher) than that observed in the $2.5 \%$ dilution (Table 5 ).

\subsubsection{Orange vinasse}

The frequency of CA and MN observed in the meristematic region showed the genotoxic potential of the vinasse, since these alterations were statistically significant compared to the control. Nuclear bud, anaphasic bridge, MN, chromosomal loss and chromosomal break were the observed alterations. Table 3 shows all the alterations observed. The highest dilution had a higher frequency of CA and MN (Table 4). In the cells of the $\mathrm{F}_{1}$ region, both dilutions induced $\mathrm{MN}$ formation; in the $5 \%$ dilution, the FMN was 1.7 -fold higher compared to the $2.5 \%$ dilution (Table 5).

\section{Discussion}

According to the results obtained in this study, both types of vinasse showed genotoxicity to the organism employed in the experiments, since they were able to induce CA and MN in meristematic cells. In the cells of the $\mathrm{F}_{1}$ region, it was possible to analyze the persistence of DNA damage through the presence of $\mathrm{MN}$, suggesting the mutagenic potential of the samples.

CA are characterized by changes in chromosome structure or in the total number of chromosomes and can occur spontaneously or as a result of exposure to chemical or physical agents (Russell, 2002). MN, small cytoplasmic masses of chromatin with a rounded shape, are the result of chromosomal breaks and/or aneuploidy during cell division. Due to an error they are not included in the main nucleus at the end of the division (Grisolia and Starling, 2001; Ramirez and Saldanha, 2002). So, the joint assessment of these alterations allows the detection of DNA damage resulting from exposure to several toxic agents (Fenech, 2000; Leme and Marin-Morales, 2009).

Both sugar cane and orange vinasse are characterized by different substances at different concentrations and, for this reason, are considered complex mixtures. The physicochemical analysis of the samples herein studied showed some differences between the two residues.

Table 2

Metal analysis of the two vinasse samples.

\begin{tabular}{|c|c|c|c|c|}
\hline Parameters & MVA & Method & Sugarcane vinasse & Orange vinasse \\
\hline Aluminum (mg/L) & 0,2 & 3030E USEPA 6010C & 0,47 & - \\
\hline Antimony (mg/L) & 0,005 & USEPA $6010 \mathrm{C}$ & $<\mathrm{QL}$ & $<\mathrm{QL}^{*}$ \\
\hline Arsenio (mg/L) & 0,01 & USEPA 6010C & $<\mathrm{QL}$ & $<\mathrm{QL}^{*}$ \\
\hline Barium (mg/L) & 0,7 & 3030E USEPA 6010C & 0,218 & $1,118^{*}$ \\
\hline Boron (mg/L) & 0,5 & 3030E USEPA 6010C & $<\mathrm{QL}$ & $<\mathrm{QL}^{*}$ \\
\hline Cadmium (mg/L) & 0,005 & 3030E USEPA 6010C & $<\mathrm{QL}$ & $<\mathrm{QL}^{*}$ \\
\hline Lead $(\mathrm{mg} / \mathrm{L})$ & 0,01 & 3030E USEPA 6010C & $<\mathrm{QL}$ & $<\mathrm{QL}^{*}$ \\
\hline Cobalt (mg/L) & 0,005 & 3030E USEPA 6010C & 0,014 & $<\mathrm{QL}^{*}$ \\
\hline Copper (mg/L) & 2 & 3030E USEPA 6010C & 0,155 & $<\mathrm{QL}^{*}$ \\
\hline Chromium (mg/L) & 0,05 & 3030E USEPA 6010C & $<\mathrm{QL}$ & $<\mathrm{QL}^{*}$ \\
\hline Iron $(\mathrm{mg} / \mathrm{L})$ & 0,3 & 3030E USEPA 6010C & 8,531 & - \\
\hline Manganese (mg/L) & 0,4 & 3030E USEPA 6010C & $3,110^{*}$ & - \\
\hline Mercury (mg/L) & 0,001 & USEPA 6010C & $<\mathrm{QL}$ & $<\mathrm{QL}$ \\
\hline Molybdenum (mg/L) & 0,07 & 3030E USEPA 6010C & $<\mathrm{QL}$ & $<\mathrm{QL}^{*}$ \\
\hline Níckel (mg/L) & 0,02 & 3030E USEPA 6010C & 0,029 & $<\mathrm{QL}^{*}$ \\
\hline SIlver (mg/L) & 0,05 & 3030E USEPA 6010C & $<\mathrm{QL}$ & $<\mathrm{QL}^{*}$ \\
\hline Selenium (mg/L) & 0,01 & 3030E USEPA 6010C & $<\mathrm{QL}$ & $<\mathrm{QL}^{*}$ \\
\hline Zinc $(\mathrm{mg} / \mathrm{L})$ & 5 & 3030E USEPA 6010C & 0,625 & $0,813^{*}$ \\
\hline
\end{tabular}

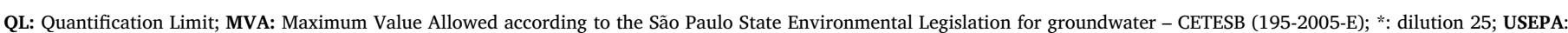
United State Environmental Protection Agency. 

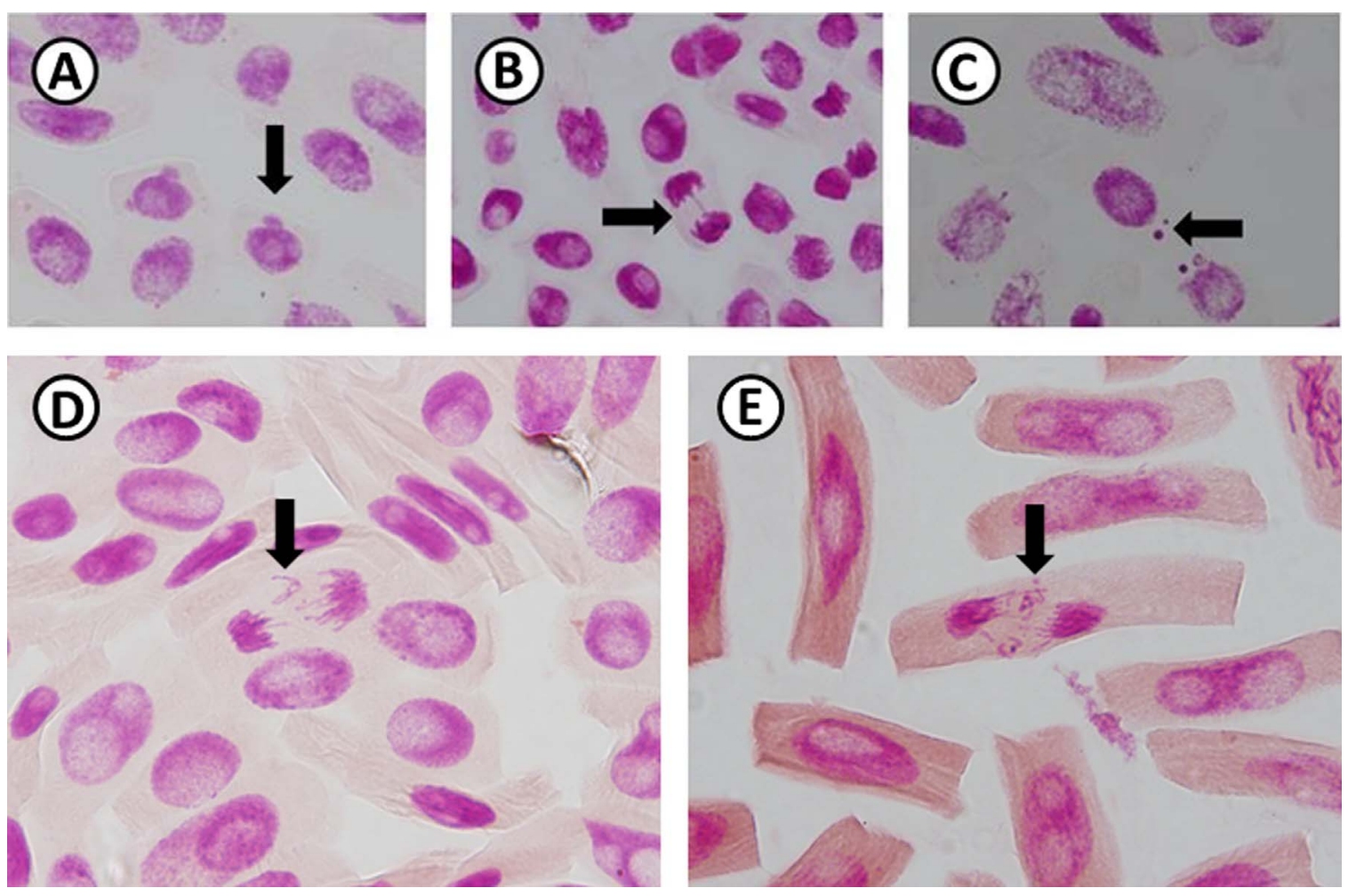

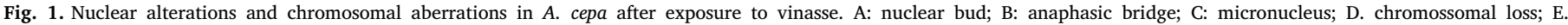
chromossomal breaks. Magnification: $1000 \times$.

Table 3

Chromossomal aberrations and MN observed in meristematic cells of A. cepa exposed to different dilutions of sugar cane and orange vinasse.

\begin{tabular}{|c|c|c|c|c|c|c|}
\hline & Nuclear bud & Chromosomal loss & Chromosomal bridge & Chromosomal break & MN & Total of cells ${ }^{a}$ \\
\hline NC & 0 & 0 & 0 & 0 & 0 & 14,396 \\
\hline MMS & 30 & 51 & 38 & 34 & 1509 & 14,098 \\
\hline SV $2.5 \%$ & 129 & 3 & 10 & 0 & 250 & 13,998 \\
\hline SV 5\% & 103 & 5 & 31 & 2 & 208 & 13,963 \\
\hline OV $2.5 \%$ & 44 & 3 & 8 & 1 & 182 & 14,634 \\
\hline OV $5 \%$ & 125 & 1 & 23 & 0 & 366 & 14,320 \\
\hline
\end{tabular}

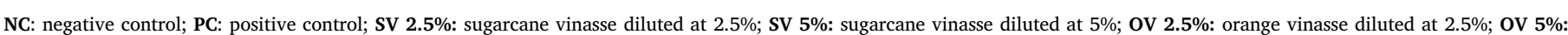
orange vinasse diluted at $5 \%$; MN: micronucleus.

a total of cells analyzed in triplicate.

Table 4

Mean values and standard deviation of chromosomal aberrations and micronucleus frequency observed in meristematic cells of $A$. cepa exposed to two different dilutions of sugarcane and orange vinasse.

\begin{tabular}{lll}
\hline Treatments & ICA & FMN \\
\hline NC & $0 \pm 0$ & $0 \pm 0$ \\
PC & $1.08 \pm 0.93^{*}$ & $10.77 \pm 6.73^{*}$ \\
SV 2.5\% & $1.02 \pm 0.62^{*}$ & $1.78 \pm 0.51^{*}$ \\
SV 5\% & $1.02 \pm 0.47^{*}$ & $1.49 \pm 0.32^{*}$ \\
OV 2.5\% & $0.38 \pm 0.32^{*}$ & $1.24 \pm 0.47^{*}$ \\
OV 5\% & $1.04 \pm 0.72^{*}$ & $2.55 \pm 0.97^{*}$ \\
\hline
\end{tabular}

NC: negative control; PC: positive control; SV 2.5\%: sugarcane vinasse diluted at $2.5 \%$; SV 5\%: sugarcane vinasse diluted at $5 \%$; OV $2.5 \%$ : orange vinasse diluted at $2.5 \%$; OV 5\%: orange vinasse diluted at 5\%; ICA: Index of Chromossomal Aberrations; FMN: Frequency of Micronucleus.

${ }^{*} \mathrm{p}<0.05$ in relation to NC.

However, the characteristics commonly observed in all types of vinasse, such as low $\mathrm{pH}$, high concentrations of BOD and COD and large amounts of potassium, were found in both samples. The sugar cane vinasse showed a higher number of metals (aluminum, cobalt, iron,
Table 5

Mean values and standard deviation of micronucleus frequency observed in cells of the $F_{1}$ region in $A$. cepa exposed to two different dilutions of sugarcane and orange vinasse.

\begin{tabular}{ll}
\hline Treatments & FMN \\
\hline CN & $0.04 \pm 0.11$ \\
PC & $2.54 \pm 0.59^{*}$ \\
SV 2.5\% & $0.72 \pm 0.28^{*}$ \\
SV 5\% & $1.6 \pm 0.44^{*}$ \\
OV 2.5\% & $0.92 \pm 0.36^{*}$ \\
OV 5\% & $1.6 \pm 0.37^{*}$ \\
\hline
\end{tabular}

NC: negative control; PC: positive control; SV 2.5\%: sugarcane vinasse diluted at $2.5 \%$; SV $5 \%$ : sugarcane vinasse diluted at $5 \%$; OV $2.5 \%$ : orange vinasse diluted at $2.5 \%$; OV 5\%: orange vinasse diluted at 5\%; FMN: Frequency of Micronucleus.

$$
* \mathrm{p}<0.05 \text { in relation to NC. }
$$

manganese and nickel) in higher concentrations than those allowed by Brazilian environmental law for groundwater (CETESB, 2005). In the orange vinasse, only the concentration of barium was higher than that 
allowed by the Brazilian government. Regardless of its raw material, the main constituent of vinasse is organic matter, especially potassium, calcium and magnesium (Giachini and Ferraz, 2009; Ramalho and Sobrinho, 2001) and all these factors contribute to its potential polluting power (Freire and Cortez, 2000; Tavares et al., 1998).

Thus, the analyses obtained by the physicochemical characterization of the two types of vinasse, associated with the results of the bioassays with $A$. серa, revealed the toxicity characteristics commonly presented by this type of effluent.

Several authors have reported that the genotoxicity of vinasse is due to the presence of metals such as $\mathrm{Cd}, \mathrm{Cr}, \mathrm{Ni}, \mathrm{Pb}, \mathrm{K}, \mathrm{P}, \mathrm{S}, \mathrm{Fe}, \mathrm{Mn}, \mathrm{Zn}$ and $\mathrm{Cu}$ (Pedro-Escher et al., 2014; Souza et al., 2013; Srivastava and Jain, 2010). Pedro-Escher et al. (2016) observed that sugar cane vinasse applied to soil at different dilutions $(12.5 \%, 25 \%$ and $50 \%)$ was responsible for inducing CA such as adhesion and chromosomal loss and polyploidy in meristematic cells of A. cepa. Similar results were observed by Christofoletti et al. (2013b), even when the concentration of metals present in the sugar cane vinasse was below those allowed by the environmental legislation.

There are some studies performed with higher plants that have shown that the genotoxic potential of metals can induce changes in the structure and number of chromosomes and disturbances during the mitotic process (Fiskesjö, 1993; Minissi and Lombi, 1997). Among the metals found in the vinasse herein analyzed, barium was detected in higher concentrations than allowed in both samples. This metal is commonly found in the tissues of many plants, but in small amounts (4-50 mg/kg); in larger quantities it can be toxic and growth-inhibitory (Chaudhry et al., 1977; Coscione and Berton, 2009; Kuperman et al., 2006; Llugany et al., 2000). Also, it is included in the list of hazardous substances from the Agency for Toxic Substances and Disease Registry (ATSDR, 2010).

The metals aluminum, cobalt, copper, iron, manganese and nickel were measured in higher concentrations than allowed only in sugar cane vinasse. As for barium, these metals are also related to genotoxicity in different organisms (Boeck et al., 1998; Francisco et al., 2014; Lima et al., 2011; Van Goethem et al., 1997; Yildiz et al., 2009). In cells, metals lead to genotoxicity through different processes, but oxidative stress is the most common for nickel (Chen et al., 2003), copper (Thounaojam et al., 2012), cobalt (Alarifi et al., 2013) and iron (Ahamed et al., 2013).

As the orange vinasse showed a lower amount and concentration of metals, one could expect that it would display lower levels of genotoxicity. However, considering the results, it was observed that the genotoxic and mutagenic potential in both effluents were similar. However, little is known about the toxicity of orange vinasse, since studies on it are new. According to Rezzadori and Benedetti (2009), there is recent interest in adding value to this by-product and, at the same time, decreasing and preventing its toxicity to the environment.

Although metals seem to be the main vinasse genotoxicity factor, some physicochemical parameters may interfere its toxicity. Physicochemical parameters such as $\mathrm{pH}$, chemical oxygen demand (COD) and biochemical oxygen demand (BOD) are routinely used for monitoring and assessing water quality (Oliveira et al., 2012).

High BOD indices, as observed in our analysis, may result in reduction and even elimination of oxygen in the water source, causing substantial changes in the ecosystem (Fiorucci and Benedetti Filho, 2005). In situations of apoxia or hypoxia, the genetic material is likely to be damaged. Snyder and Diehl (2005) demonstrated hypoxia alone may elevate $\mathrm{MN}$ frequency and be genotoxic in mice. Severe hypoxia can also provokes DNA damage in fish, as observed by Negreiros et al. (2011). Two possible mechanisms can be responsible for this situation: oxidative stress and inhibition of the DNA repair system (Slobodskova et al., 2012).

According to the literature, ammoniacal nitrogen (Wang et al., 2007) and sodium $\left(\mathrm{Na}^{+}\right)$and potassium $\left(\mathrm{K}^{+}\right)$salts (Brusick, 1986) also presents genotoxic properties. Introduction of high levels of $\mathrm{Na}^{+}$and
$\mathrm{K}^{+}$ions might prevent the sequestering of magnesium ions $\left(\mathrm{Mg}^{2+}\right)$ required for the normal maintenance of chromatin integrity. A reduction in effective $\mathrm{Mg}^{2+}$ ion concentration by high levels of $\mathrm{K}^{+}$or $\mathrm{Na}^{+}$ could also interfere with normal DNA replication (Brusick, 1986).

However, not all the physicochemical parameters can be related to the vinasse genotoxicity. Magnesium and calcium, for example, are not known to be toxic to the genetic material. Magnesium is an essential ion to the organism and plays an important role in genomic stability, such as in DNA replication and protein synthesis (Hartwig, 2001); calcium is a protective agent and can reduce genotoxicity (Aboul-Ela, 2002; Taspinar et al., 2011).

Considering the fact that vinasse is a complex substance, it is not possible to state which of the compounds or physicochemical characteristics are responsible for its genotoxicity. In such cases, the ability of a compound to interfere in the action of another one should be noticed (Azevedo and Chasin, 2004). The $\mathrm{pH}$, for example, can interfere with the bioavailability of metals, since it may contribute to their precipitation in the environment (CETESB, 2009). Low levels of pH may also reduce the fidelity of the DNA replication and repair enzymes and this could conceivably produce genotoxic effects (Brusick, 1986). Pedro-Escher et al. (2016) and Christofoletti et al. (2013b) stated that low $\mathrm{pH}$ was the one of the parameters responsible for the genotoxicity observed in their vinasse samples.

\section{Conclusion}

According to the results of CA and FMN in meristematic cells of $A$. cepa and FMN in the $F_{1}$ region, it can be concluded that these two effluents have genotoxic potential and are potentially mutagenic at both dilutions. Our results also showed that the genotoxicity and mutagenic potential are similar in both types of vinasse. It is suggested that the presence of metals and low $\mathrm{pH}$ are the main parameters responsible for the toxicity. Thus, further studies involving these substances, mainly with orange vinasse, are necessary in order to ensure safe use as fertilizers in agriculture activity.

\section{Conflict of interest}

The authors declare that they have no conflict of interest.

\section{Acknowledgements}

The authors thank Fundação de Amparo à Pesquisa do Estado de São Paulo (FAPESP, process no. 2014/17998-7 and 2012/50197-2) for financial support.

\section{References}

Aboul-Ela, E.I., 2002. The protective effect of calcium against genotoxicity of lead acetate administration on bone marrow and spermatocyte cells of mice in vivo. Mutat. Res./ Genet.Toxicol. Environ. Mutagen. 516 (1), 1-9.

Agency for Toxic Substances and Disease Registry - ATSDR, 2010. Priority List of Hazardous Substances. Available from: 〈http://www.atsdr.cdc.gov/cercla〉. (Accessed on 22 September 2015).

Ahamed, M., Alhadlaq, H., Alam, J., Khan, M., Ali, D., Alarafi, S., 2013. Iron oxide nanoparticle-induced oxidative stress and genotoxicity in human skin epithelial and lung epithelial cell lines. Curr. Pharm. Des. 19 (37), 6681-6690.

Alarifi, S., Ali, D., Suliman, O.A., Ahamed, M., Siddiqui, M.A., Al-Khedhairy, A.A., 2013. Oxidative stress contributes to cobalt oxide nanoparticles-induced cytotoxicity and DNA damage in human hepatocarcinoma cells. Int. J. Nanomed. 8, 17-23.

Aloisi, R.R., Demattê, J.A.M., Fiorio, P.R.A., 2001. Aplicação de resíduos da indústria cítrica em três solos de São Paulo e o crescimento inicial de planta de milho em casa de vegetação. Laranja. Cordeirópolis 22 (2), 533-548.

Azevedo, F.A., Chasin, A.A.M., 2004. As Bases Toxicológicas da Ecotoxicologia. Rima, São Paulo, pp. 340.

Batista, N.J.C., Cavalcante, A.A.C.M., Oliveira, M.G., Medeiros, E.C.N., Machado, J.L., Evangelista, S.R., Dias, J.F., Santos, C.E.I., Duarte, A., Silva, F.R., Silva, J., 2016. Genotoxic and mutagenic evaluation of water samples from a river under the influence of different anthropogenic activities. Chemosphere 164, 134-141.

Boeck, M., Lison, D., Kirsch-Volders, M., 1998. Evaluation of the in vitro direct and indirect genotoxic effects of cobalt compounds using the alkaline comet assay. 
Influence of interdonor and interexperimental variability. Carcinogenesis 19 (11), 2021-2029.

Brusick, D., 1986. Genotoxic effects in cultured mammalian cells produced by low pH treatment conditions and increased ion concentrations. Environ. Mol. Mutagen. 8 (6), 879-886.

CETESB - Companhia de Tecnologia de Saneamento Ambiental. 2009. Qualidade das águas interiores no estado de São Paulo. Available from: (http://cetesb.sp.gov.br/ aguas-interiores/wp-content/uploads/sites/32/2013/11/variaveis.pdf). (Accessed on 27 September 2005).

CETESB - Companhia de Tecnologia de Saneamento Ambiental. 2005. Decisão de diretoria № 195-2005 da Companhia de Tecnologia de Saneamento Ambiental de São Paulo. Valores orientadores para solos e águas subterrâneas no estado de São Paulo. Available from: 〈http://solo.cetesb.sp.gov.br/solo/valores-orientadores-para-solo-eagua-subterranea/ $\rangle$. (Accessed on 27 September 2015).

Chaudhry, F.M., Wallace, A., Mueller, R.T., 1977. Ba toxicity in plants. Commun. Soil Sci. Plant Anal. 8, 795-797.

Chen, C.Y., Wang, Y.F., Huang, W.R., Huang, Y.T., 2003. Nickel induces oxidative stress and genotoxicity in human lymphocytes. Toxicol. Appl. Pharmacol. 189 (3), 153-159.

Christofoletti, C.A., Pedro-Escher, J., Correia, J.E., Marinho, J.F.U., Fontanetti, C.S., 2013a. Sugar cane vinasse: environmental implications of its use. Waste Manag. 33, 2752-2761.

Christofoletti, C.A., Pedro-Escher, J., Fontanetti, C.S., 2013b. Assessment of the genotoxicity of two agricultural residues after processing by diplopods using the Allium cepa assay. Water Air Soil Pollut. 224 (4), 1-14.

Christofoletti, C.A., Francisco, A., Pedro-Escher, J., Gastaldi, V.D., Fontanetti, C.S., 2016. Diplopods as soil bioindicators of toxicity after application of residues from sewage treatment plants and ethanol industry. Microsc. Microanal. 22, 1098-1110.

Citrosuco, 2016. Subprodutos da indústria cítrica. Available from: 〈http://www. citrosuco.com.br/pt/produtos.php\#subprodutos $\rangle$. (Accessed on 26 August 2016).

Correia, J.E., Christofoletti, C.A., Marcato, A.C.C., Marinho, J.F.U., Fontanetti, C.S., 2017. Histopathological analysis of tilapia gills (Oreochromis niloticus Linnaeus, 1758) exposed to sugarcane vinasse. Ecotoxicol. Environ. Saf. 135, 319-326.

Coscione, A.R., Berton, R.S., 2009. Barium extraction potential by mustard, sunflower and castor bean. Sci. Agric. 66 (1), 59-63.

EPE - Empresa de Pesquisa Energética, 2015. Análise de Conjuntura dos Biocombustíveis, Janeiro 2014 - Dezembro 2014, Ministério de Minas e Energia, Brazil.

España-Gamboa, E., Mijangos-Cortes, J., Barahona-Perez, L., Dominguez-Maldonado, J., Hernández-Zarate, G., Alzate-Gaviria, L., 2011. Vinasses: characterization and treatments. Waste Manag. Res. 29 (12), 1235-1250.

Fenech, M., 2000. The in vitro micronucleus technique. Mutat. Res./Fundam. Mol. Mech. Mutagen. 455 (1), 81-95.

Francisco, A., Christofoletti, C.A., Fontanetti, C.S., 2014. Avaliação dos parâmetros permitidos de níquel para corpos de água doce utilizando o teste de Allium cepa. Semin.: Ciências Biol. e da Saúde 35 (1), 49-60.

Freire, W.J., Cortez, L.A., 2000. Vinhaça de Cana-de-açúcar. Agropecuária, Guaíba, pp. 203.

Fiorucci, A.R., Benedetti Filho, E., 2005. A importância do oxigênio dissolvido em ecossistemas aquáticos. Quím. Nova na Esc. (22), 10-16.

Fiskesjö, G., 1993. The Allium cepa test in wastewater monitoring. Environ. Toxicol. Water Qual. 8, 291-298.

Giachini, C.F., Ferraz, M.V., 2009. Benefícios da utilização de vinhaça em terras de plantio de cana-de-açúcar - revisão de literatura. Rev. Científica Eletrôn. De. Agron. $3,1-15$.

Grisolia, C.K., Starling, F.L.R.M., 2001. Micronuclei monitoring of fishes from Lake Paranoá, under influence of sewage treatment plant discharges. Mutat. Res. 491, 39-44.

Hartwig, A., 2001. Role of magnesium in genomic stability. Mutation Res./Fundam. Mol. Mech. Mutagen. 475 (1), 113-121.

Kuchy, A.H., Wani, A.A., Kamili, A.N., 2016. Cytogenetic effects of three commercially formulated pesticides on somatic and germ cells of Allium cepa. Environ. Sci. Pollut. Res. Int. 23, 6895-6906.

Kuperman, R.G., Checkal, R.T., Simini, M., Phillips, C.I., Speicher, J.A., Barclift, D.J., 2006. Toxicity benchmarks for antimony, barium, and beryllium determined using reproduction endpoints for Folsomia candida, Eisenia fetida, and Enchytraeus crypticus. Environ. Toxicol. Chem. 25 (3), 754-762.

Laime, E.M.O., Fernandes, D.C.S., Freire, E.A., 2011. Possibilidades tecnológicas para a destinação da vinhaça: uma revisão. Rev. Trópica-Ciências Agrar. e Biol. 5, 16-29.

Leme, D.M., Marin-Morales, M.A., 2009. Allium cepa test in environmental monitoring: a review on its application. Mutat. Res. 682, 71-81.

Lima, P.D.L., Vasconcellos, M.C., Montenegro, R.C., Bahia, M.O., Antunes, L.M.G., Costa, E.T., Burbano, R.R., 2011. Genotoxic effects of aluminum, iron and manganese in human cells and experimental systems: a review of the literature. Human. Exp. Toxicol. 30, 1435-1444.

Llugany, M., Poschenrieder, C., Barcelo, J., 2000. Assessment of Ba toxicity to bush beans. Arch. Environ. Contam. Toxicol. 39, 440-444.

Lutterbeck, C.A., Kern, D.I., Machado, E.L., Kümmerer, K., 2015. Evaluation of the toxic effects of four anti-cancer drugs in plant bioassays and its potency for screening in the context of waste water reuse for irrigation. Chemosphere 135, 403-410.

Ma, T.H., 1999. The international program on plant bioassays and the report of the follow-up study after the hands-on workshop in China. Mutat. Res. 426, 103-106.

Marinho, J.F.U., Correia, J.E., de Castro Marcato, A.C., Pedro-Escher, J., Fontanetti, C.S., 2014. Sugar cane vinasse in water bodies: impact assessed by liver histopathology in tilapia. Ecotoxicol. Environ. Saf. 110, 239-245.
Martins, N.C.M., Souza, V.V., Souza, T.S., 2016. Cytotoxic, genotoxic and mutagenic effects of sewage sludge on Allium cepa. Chemosphere 148, 481-486.

Minissi, S., Lombi, E., 1997. Heavy metal content and mutagenic activity evaluated by Vicia faba micronucleus test, of Tiber river sediments. Mutat. Res. 393, 17-21.

Negreiros, L.A., Silva, B.F., Paulino, M.G., Fernandes, M.N., Chippari-Gomes, A.R., 2011. Effects of hypoxia and petroleum on the genotoxic and morphological parameters of. Hippocampus reidi. Compar. Biochem. Physiol., Part C 153, 408-414.

Neto, J.A.L., 2008. Monitoramento de Componentes Químicos da Vinhaça Aplicados em Diferentes Tipos de Solo (Doctoral thesis). Luiz de Queiroz, Escola Superior de Agricultura.

Oliveira, J.P.W., dos Santos, R.N., Pibernat, C.C., Boeira, J.M., 2012. Genotoxicity and Physical Chemistry Analysis of waters from Sinos River (RS) using Allium cepa and Eichhornia crassipesas bioindicators. Biochem. Biotechnol. Rep. 1 (1), 15-22.

Pedro-Escher, J., Christofoletti, C.A., Ansoar-Rodríguez, Y., Fontanetti, C.S., 2016. Sugarcane vinasse, a residue of ethanol industry: toxic, cytotoxic and genotoxic potential using the Allium cepa test. J. Environ. Prot. 7, 602-612.

Pedro-Escher, J., Maziviero, G.T., Fontanetti, C.S., 2014. Mutagenic action of sugar cane vinasse in the Tradescantia pallida test system. J. Ecosyst. Ecogr. 4, 145.

Pedrosa, E.M.R., Rolim, M.M., Albuquerque, P.H.S., Cunha, A.C., 2005. Supressividade de nematóides em cana-de-açúcar por adição de vinhaça ao solo. Rev. Bras. De. Eng. Agríc. e Ambient. 9, 197-201.

Pichler, C., Filipic, M., Kundi, M., Rainer, B., Knasmueller, S., Misik, M., 2014. Assessment of genotoxicity and acute toxic effect of the imatinib mesylate in plant bioassays. Chemosphere 115, 54-58.

Ramalho, J.F.G.P., Sobrinho, N.M.B.A., 2001. Metais pesados em solos cultivados com cana-de-açúcar pelo uso de resíduos agroindustriais. Rev. Floresta e Ambient. 8 (1), $120-129$.

Ramirez, A., Saldanha, P.H., 2002. Micronucleus investigation of alcoholic patients with oral carcinomas. Genet. Mol. Res. 1 (3), 246-260.

Rank, J., Nielsen, M.H., 1997. Allium cepa anaphase-telophase root tip chromosome aberration assay on N-methyl-N-nitrosourea, maleic hydrazide, sodium azide, and ethyl methanesulfonate. Mutat. Res. 390, 121-127.

Rezzadori, K., Benedetti, S., 2009. Proposições para valorização de resíduos do processamento do suco de laranja. In: Proceedings of the International Workshop Advances In Cleaner Production. São Paolo, Brazil. pp. 1-11.

Rodríguez, Y.A., Christofoletti, C.A., Pedro, J., Bueno, O.C., Malaspina, O., Ferreira, R.A.C., Fontanetti, C.S., 2015. Allium cepa and Tradescantia pallida bioassays to evaluate effects of the insecticide imidacloprid. Chemosphere 120, 438-442.

Rosa, M.F., Souza Filho, M.S.M., Figueiredo, M.C.B., Morais, J.P.S., Santaella, S.T., Leitão, R.C., 2011. Valorização de resíduos da agroindústria. II Simpósio Internacional sobre Gerenciamento de Resíduos Agropecuários e Agroindustriais - II SIGERA, Vol. 1. Foz do Iguaçu, PR, Brazil.

Russell, P.J., 2002. Chromosomal mutation. In: Cummings, B. (Ed.), Genetics. Pearson Education Inc, San Francisco, pp. 595-621.

Saverini, M., Catanzaro, I., Sciandrello, G., Avellone, G., Indelicato, S., Marcì, G., Palmisano, L., 2012. Genotoxicity of citrus wastewater in prokaryotic and eukaryotic cells and efficiency of heterogeneous photocatalysis by $\mathrm{TiO}_{2}$. J. Photochem. Photobiol. B: Biol. 108, 8-15.

Silva, M.A.S., Griebeler, N.P., Borges, L.C., 2007. Uso de vinhaça e impactos nas propriedades do solo e lençol freático. Rev. Bras. De. Eng. Agríc. 11 (1).

Slobodskova, V.V., Zhukovskaya, A.F., Chelomin, V.P., 2007. DNA damage in the gill cells of the marine scallop Mizuhopecten yessoensis during anoxic stress and aerobic recovery. Ocean Sci. J. 41 (1), 160-165.

Snyder, R.D., Diehl, M.S., 2005. Hypoxia-induced micronucleus formation in mice. Drug and Chem. Toxicol. 28 (4), 373-378.

Souza, T.S., Hencklein, F.A., Angelis, D.D.F., Fontanetti, C.S., 2013. Clastogenicity of landfarming soil treated with sugar cane vinasse. Environ. Monit. Assess. 185 (2), 1627-1636.

Souza, R.B., de Souza, C.P., Bueno, O.C., Fontanetti, C.S., 2017. Genotoxicity evaluation of two metallic-insecticides using Allium cepa and Tradescantia pallida: a new alternative against leaf-cutting ants. Chemosphere 168, 1093-1099.

Srivastava, S., Jain, R., 2010. Effect of distillery spent wash on cytomorphological behavior of sugarcane settlings. J. Environ. Biol. 31, 809-812.

Taspinar, M.S., Agar, G., Alpsoy, L., Yildirim, N., Bozari, S., Sevsay, S., 2011. The protective role of zinc and calcium in Vicia faba seedlings subjected to cadmium stress. Toxicol. Ind. Health 27 (1), 73-80.

Tavares, V.B., Sivieri, K., Ceron, C.R., Silva, R., Trabuco, E., Lombardi, F.R., Gomes, E., 1998. Utilização do resíduo líquido de indústria de processamento de suco de laranja como meio de cultura de Penicillium citrinum: depuração biológica do resíduo e produção de enzima. Quím. Nova 21 (6), 722-725.

Thounaojam, T.C., Panda, P., Mazumdar, P., Kumar, D., Sharma, G.D., Sahoo, L., Sanjib, P., 2012. Excess copper induced oxidative stress and response of antioxidants in rice. Plant Physiol. Biochem. 53, 33-39.

Wang, L.S., Hu, H.Y., Wang, C., 2007. Effect of ammonia nitrogen and dissolved organic matter fractions on the genotoxicity of wastewater effluent during chlorine disinfection. Environ. Sci. Technol. 41 (1), 160-165.

Van Goethem, F., Lison, D., Kirsch-Volders, M., 1997. Comparative evaluation of the in vitro micronucleus test and the alkaline single cell gel electrophoresis assay for the detection of DNA damaging agents: genotoxic effects of cobalt powder, tungsten carbide and cobalt-tungsten carbide. Mutat. Res./Genet. Toxicol. Environ. Mutagen. 392 (1), 31-43.

Yildiz, M., Cigerci, I.H., Konuk, M., Fidan, A.F., Terzi, H., 2009. Determination of genotoxic effects of copper sulphate and cobalt chloride in Allium cepa root cells by chromosome aberration and comet assays. Chemosphere 75 (7), 934-938. 